\title{
PERILAKU KELUARGA DALAM MENGONTROL FAKTOR RISIKO PENYAKIT HIPERTENSI PADA MASYARAKAT DESA DI PONOROGO
}

\author{
Saiful Nurhidayat \\ Prodi S1 Keperawatan Fakultas IImu Keperawatan Universitas Muhammadiyah Ponorogo \\ Jl. Budi Utomo No.10, Ronowijayan, Kabupaten Ponorogo, Jawa Timur 63471 \\ saiful.nurhidayat2@gmail.com
}

\begin{abstract}
Hypertension is influenced by multiple risk factors, both endogenous such as age, gender and genetics, as well as exogenous such as over weight, salt intake, smoking and coffee consumption. Family behaviour is indispensable in controlling the risk factors of hypertension. The purpose of this study was to get an insight of family behaviour in controlling hypertension risk factors and to analyze the dominant family behaviour in controlling the risk factors of hypertension in the rural communities. The study was conducted in the rural communities of Slahung Ponorogo, sample of 100 respondents by purposive sampling. The design was quantitative with cross sectional design, the instruments was questionnaires and observation sheets. Analysis was using frequency distribution. The results showed that the behaviour of the family in controlling risk factors of hypertension in the rural communities of Ponorogo was mostly bad behavior, as many as 51 respondents (51\%). The model of family behavior in controlling the risk factors of hypertension in the rural communities of Ponorogo was dominantly controlling healthy lifestyle, that is the family provides time for regular exercises, maintains the home atmosphere from peaceful and comfortable, resolves problems in the family as well, does not smoke and check healthy regularly.
\end{abstract}

Keywords: family behaviour, risk factors, hypertension.

\begin{abstract}
Abstrak : Hipertensi dipengaruhi oleh faktor risiko ganda, baik yang bersifat endogen seperti usia, jenis kelamin dan genetik, maupun yang bersifat eksogen, seperti kelebihan berat badan, konsumsi garam, rokok dan kopi. Perilaku keluarga sangat diperlukan dalam mengontrol faktor risiko penyakit hipertensi. Tujuan penelitian ini adalah untuk mendapatkan gambaran perilaku keluarga dalam mengontrol faktor resiko penyakit hipertensi dan untuk menganalisis perilaku keluarga yang dominan dalam mengontrol faktor risiko penyakit hipertensi pada masyarakat desa. Penelitian dilakukan pada masyarakat desa Slahung Kabupaten Ponorogo, sampel 100 responden secara purposive sampling. Desain kuantitatif dengan rancangan cross sectional, instrumen menggunakan kuesioner dan lembar observasi. Analisis menggunakan distribusi frekuensi. Hasil penelitian menunjukkan perilaku keluarga dalam mengontrol faktor risiko penyakit hipertensi pada masyarakat desa di Ponorogo terbanyak adalah perilaku buruk yaitu 51 responden $(51 \%)$. Model perilaku keluarga yang dominan dalam mengontrol faktor risiko penyakit hipertensi pada masyarakat pedesaan di Kabupaten Ponorogo adalah mengontrol pola hidup sehat, yaitu keluarga menyediakan waktu olahraga secara teratur, menjaga suasana rumah yang tentram dan nyaman, menyelesaikan masalah di keluarga secara baik, tidak merokok dan kontrol kesehatan secara teratur.
\end{abstract}

Kata Kunci : perilaku keluarga, faktor risiko, penyakit hipertensi.

\section{PENDAHULUAN}

Hipertensi adalah suatu peningkatan abnormal tekanan darah dalam pembuluh darah arteri secara terus-menerus lebih dari suatu periode. Hipertensi dipengaruhi oleh faktor risiko ganda, baik yang bersifat endogen seperti usia, jenis kelamin dan genetik/keturunan, maupun yang bersifat eksogen seperti obesitas, konsumsi garam, rokok dan kopi (Hananta, 2011).
Insidensi hipertensi meningkat seiring dengan pertambahan usia, laki-laki memiliki risiko hipertensi lebih tinggi untuk menderita hipertensi lebih awal. Meningkatnya kelompok usia ( $\geq 40$ tahun) meningkat pula prevalensi hipertensi. Hipertensi bersifat diturunkan atau bersifat genetik. Individu dengan riwayat keluarga hipertensi mempunyai risiko dua kali lebih besar untuk menderita hipertensi daripada 
individu yang tidak mempunyai keluarga dengan riwayat hipertensi. Obesitas juga dapat meningkatkan kejadian hipertensi. Beberapa studi menunjukkan bahwa seseorang yang mempunyai kelebihan berat badan lebih dari $20 \%$ dan hiperkolesterol mempunyai risiko yang lebih besar terkena hipertensi. Hal ini disebabkan lemak dapat menimbulkan sumbatan pada pembuluh darah sehingga dapat meningkatkan tekanan darah. Jika asupan garam antara 7-15 gram perhari prevalensi hipertensi meningkat menjadi $15-20 \%$. Pada kalangan penduduk umur 25-65 tahun dengan jenis kelamin laki-laki mempunyai kebiasaan merokok cukup tinggi yaitu 54,5\%. Seseorang menghisap rokok lebih dari satu pak rokok sehari menjadi 2 kali lebih rentan terhadap hipertensi dari pada mereka yang tidak merokok. Kopi adalah bahan minuman yang banyak mengandung kafein. Kopi juga berakibat buruk pada jantung. Kafein dapat menstimulasi jantung untuk bekerja lebih cepat sehingga mengalirkan lebih banyak cairan setiap detiknya. Kebiasaan minum kopi didapatkan dari satu cangkir kopi mengandung 75-200 mg kafein, sehingga minum kopi lebih dari empat cangkir sehari dapat meningkatkan tekanan darah sistolik sekitar $10 \mathrm{mmHg}$ dan tekanan darah diastolik sekitar 8 $\mathrm{mmHg}$ (Sutedjo, 2006).

Permasalahan pada penelitian ini adalah bagaimana perilaku keluarga dalam mengontrol faktor resiko penyakit hipertensi pada masyarakat pedesaan di Kabupaten Ponorogo?. Apakah model perilaku keluarga yang dominan dalam mengontrol faktor resiko penyakit hipertensi pada masyarakat pedesaan di Kabupaten Ponorogo?

\section{METODE PENELITIAN}

Penelitian ini merupakan penelitian kuantitatif dengan rancangan cross sectional. Rancangan ini digunakan untuk mempelajari perilaku keluarga dalam mengontrol factor risiko penyakit hipertensi dan mengkaji hubungan antara variable karakteristik umum dan khusus yang dilakukan secara serentak dalam satu waktu pada masyarakat desa Slahung Kecamatan Slahung Kabupaten Ponorogo.

Teknik sampling yang digunakan adalah Purposive Sampling dengan besar sampel 100 responden. Peneliti menggunakan instrumen berupa lembar kuesioner untuk umur, jenis kelamin, pendidikan, pekerjaan, hubungan keluarga, informasi dan sumber informasi serta perilaku keluarga dalam mengontrol factor risiko hipertensi. Untuk pengukuran tekanan darah peneliti menggunakan tensimeter pegas dengan merk onemed.

Dalam penelitian ini peneliti menggunakan likert scale yang terdiri dari pernyataan favourable dan pernyataan unfavorable. Keluarga diminta pendapatnya mengenai suatu kegiatan yang dilakukan keluarga penderita hipertensi untuk mengontrol faktor risiko hipertensi dengan kriteria: Selalu (SL), Sering (S), Jarang (J), Tidak pernah (TP).

Peralatan yang digunakan untuk mendukung penelitian adalah, timbangan, tensi meter, stetoskop, meteran. Selain itu juga alat-alat pendukung seperti alkohol, kapas alkohol, tempat kapas alkohol, tissue, alat tulis.

Pengumpulan data dengan menggunakan kuesioner, yang disusun secara terstruktur. Responden diminta menjawab pertanyaan tentang data demografi seperti jenis kelamin, umur, riwayat keturunan. Dan menjawab pernyataan tentang perilaku mengontrol faktor risiko penyakit hipertensi seperti pola diet sehat dan pola hidup sehat. Data tentang berat badan, tinggi badan, tekanan darah dan lingkar pinggang akan dilakukan pengukuran.

Proses Pengumpulan data peneliti dibantu oleh 4 tenaga. Tenaga pengumpul data berasal dari mahasiswa prodi $\mathrm{S} 1$ keperawatan. Sebelum pengambilan data untuk mempertahankan validitas dan realibilitas akan dilakukan pelatihan dan persamaan persepsi.

Analisis data dilakukan secara kuantitatif dan disesuaikan dengan tujuan yang akan dicapai pada penelitian ini dengan uji statistik. Analisis univariat digunakan untuk menganalisis secara 
deskriptif karakteristik masing-masing variabel dengan distribusi frekuensi yang akan ditampilkan dalam bentuk narasi dan tabel. Gambaran karakteristik umum subjek penelitian yang dihasilkan meliputi umur, jenis kelamin, pendidikan, pekerjaan, hubungan keluarga, informasi dan sumber informasi. Sedangkan karakteristik khusus responden adalah perilaku keluarga dalam mengontrol faktor risiko hipertensi meliputi pola makan sehat dan pola hidup sehat.

\section{HASIL DAN PEMBAHASAN}

\section{Data Umum}

Tabel 1. Distribusi Frekwensi Data Umum Pada Bulan Mei- Juni 2016 Variabel $\quad$ Frek \%

1. Umur

35- 44

45-54

55-64

65-74

2. Jenis Kelamin

Laki-laki

Perempuan

Frek

Pendidikan

$\begin{array}{lcc}\text { Pendidikan } & 30 & 30 \\ \text { SD } & 41 & 41 \\ \text { SMP } & 22 & 22 \\ \text { SMA } & 7 & 7\end{array}$

4. Pekerjaan

Guru

Swasta

Wiraswasta

Petani

PNS/Pensiunan

Tidak Bekerja

5. Hubungan

Istri/Suami

Bapak/lbu

Kakak/adik

Anak

$\begin{array}{cc}25 & 25 \\ 24 & 24 \\ 36 & 36 \\ 15 & 15 \\ 47 & 47 \\ 53 & 53 \\ & \\ 30 & 30 \\ 41 & 41 \\ 22 & 22 \\ 7 & 7\end{array}$

6. Informasi

Pernah

Tidak Pernah

7. Sumber Informasi

Med.Elektronik

Tenaga Kes

Media Cetak
Distribusi frekwensi pada tabel 1. diatas menunjukkan bahwa responden mempunyai karakteristik umum yaitu berumur 55-64 tahun 36\%, perempuan $53 \%$, berpendidikan SMP $41 \%$, bekerja sebagai petani $36 \%$, hubungan keluarga sebagai suami/istri $60 \%$, pernah mendapatkan informasi 95\%, dan bersumber dari tenaga kesehatan $44 \%$.

\section{Data Khusus}

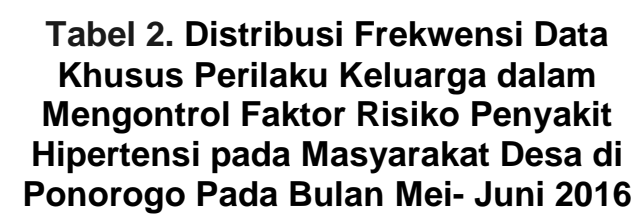

\begin{tabular}{lcc}
\hline Variabel & Frekwensi & $\%$ \\
\hline Perilaku & & \\
Baik & 49 & 49 \\
Buruk & 51 & 51 \\
\hline \multicolumn{4}{c}{ Sumber : Data Primer }
\end{tabular}

Distribusi frekwensi pada tabel 2. diatas menunjukkan bahwa dari 100 responden, perilaku keluarga buruk dalam mengontrol faktor risiko penyakit hipertensi pada masyarakat desa di Ponorogo sebesar 51\%.

\section{PEMBAHASAN}

Hasil pengumpulan data melalui lembar isian yang telah ditabulasi kemudian diinterpretasikan dan dianalisa sesuai variabel yang diteliti. Maka berikut akan disajikan pembahasan mengenai variabel tersebut.

Berdasarkan tabel 2. diketahui bahwa perilaku keluarga dalam mengontrol factor risiko penyakit hipertensi pada masyarakat desa di ponorogo diperoleh hasil perilaku buruk sejumlah 51 responden (51\%) dan perilaku baik sejumlah 49 responden (49\%). Perilaku keluarga dalam mengontrol factor risiko penyakit hipertensi dengan menjaga pola makan sehat diperoleh hasil perilaku buruk 55\% dan perilaku baik 45\%. Sedangkan perilaku keluarga dengan menjaga pola 
hidup sehat diperoleh hasil perilaku baik $55 \%$ dan perilaku buruk $45 \%$.

Faktor pertama yang mempengaruhi perilaku baik keluarga dalam mengontrol penyakit hipertensi adalah umur. Berdasarkan tabel 1. didapatkan data umur 35-44 tahun sejumlah 25 responden. Dari 25 responden tersebut diperoleh hasil 16 responden (64\%) berperilaku baik. Sesuai dengan teori Hurlock (2006) bahwa semakin cukup umur tingkat kematangan dan kekuatan seseorang yang lebih dewasa akan lebih matang dalam berfikir dan bertindak karena kematangan jiwanya yang akan berpengaruh dalam perilaku seseorang. Sehingga di usia ini keluarga mampu berperilaku baik dalam mengontrol faktor risiko penyakit hipertensi bagi anggota keluarga yang menderita hipertensi. Dengan menjaga pola makan sehat dan pola hidup sehat maka tubuh akan cukup mendapat asupan nutrisi dan terjaga pola hidup sehat keluarga sehingga faktor risiko hipertensi dapat terkontrol dan terjaga.

Sedangkan responden yang mempunyai perilaku buruk berdasarkan umur, dari 15 responden usia 65-74 tahun, 9 responden (60\%) berperilaku buruk dalam mengontrol faktor risiko penyakit hipertensi. Menurut Broadhead seperti yang dikutip Nur (2012), mengemukakan bahwa bertambahnya usia menyebabkan hubungan sosial menjadi sempit dan informasi menurun. Hal tersebut akan menyebabkan frustasi pada dirinya. Sehingga pada akhirnya perilaku keluarga dalam mengontrol faktor risiko hipertensi pada anggota keluarga yang tidak tepat menjadi buruk. Peneliti berpendapat bahwa semakin tua umur seseorang sangat mempengaruhi perilaku seseorang terhadap suatu objek atau materi sehingga perilaku-perilaku akan terbentuk menjadi buruk.

Faktor kedua yang mempengaruhi perilaku baik keluarga adalah jenis kelamin. Berdasarkan table 5.1 diperoleh data tentang jenis kelamin perempuan sejumlah 53 responden. Responden perempuan yang mempunyai perilaku baik 33 responden (62\%). Sedangkan laki-laki berjumlah 47 responden, yang mempunyai perilaku buruk sebanyak 29 responden (62\%). Menurut Heliati seperti yang di kutip Nur (2012), bahwa otak lelaki pada umumnya otak bagian kanan yang lebih aktif dan berkembang menunjukan bahwa lelaki lebih banyak memakai otaknya untuk menganalisa yang dihadapinya secara komprehensif. Perilaku pada lakilaki dipengaruhi atas dasar pertimbangan rasional atau akal yang sering disebut maskulin. Laki-laki lebih banyak tingkat aktifitasnya daripada perempuan, sehingga laki-laki berperilaku buruk karena laki-laki lebih banyak waktunya untuk bersosialisasi di luar rumah sehingga kurang memberikan cukup waktu bagi keluarga. Hal tersebut didukung dengan data pekerjaan bahwa pekerjaan wiraswasta lebih banyak berperilaku buruk yaitu 15 responden $(52 \%)$. Sedangkan yang mempunyai perilaku baik adalah perempuan, menurut Markum (2000), ciri-ciri perilaku manusia salah satunya adalah kepekaan sosial. Kepekaan sosial disini artinya kemampuan manusia untuk dapat menyesuaikan perilakunya sesuai pandangan dan harapan orang lain untuk berinteraksi dengan lingkungan sekitar. Responden perempuan lebih banyak waktunya digunakan dirumah dan sebagian digunakan untuk berinteraksi dengan lingkungan sekitar sehingga responden perempuan berperilaku baik dalam mencegah komplikasi hipertensi. Hal ini didukung oleh data bahwa pekerjaan IRT (ibu rumah tangga) mempunyai perilaku baik dalam mengontrol faktor risiko penyakit hipertensi keluarga yaitu 19 responden $(63 \%)$.

Faktor ketiga yang mempengaruhi perilaku baik keluarga adalah pendidikan. Berdasarkan tabel 1. didapatkan hasil penelitian pada responden dengan pendidikan dapat diketahui bahwa dari 22 responden berpendidikan SMA, 16 responden (59\%) berperilaku baik. Sedangkan responden berperilaku buruk adalah pendidikan SD yaitu dari 30 responden berpendidikan SD, 19 responden (63\%) berperilaku buruk. Menurut Azwar (2008), semakin seseorang berpendidikan, maka 
pemahaman akan sesuatu yang baik dan buruk dapat menentukan sistem kepercayaan sehingga konsep tersebut ikut berperan dalam menentukan sikap dan perilaku seseorang dalam suatu hal. Sehingga dengan pendidikan yang tinggi, perilaku responden akan baik dalam mengontrol faktor risiko penyakit hipertensi. Dengan pendidikan keluarga yang tinggi membuat mereka dapat melaksanakan perilaku keluarga dengan baik, dan sebaliknya jika pendidikannya rendah maka kemungkinan keluarga dapat melaksanakan perilaku keluarga juga buruk yaitu dalam menjaga pola makan sehat dan pola hidup sehat. Hal ini sesuai dengan Koentjaraningrat (2009), semakin tinggi tingkat pendidikan seseorang semakin mudah menerima informasi dan mempunyai banyak pengetahuan yang dimilikinya sehingga semakin mudah dalam melakukan tindakan dan perilaku. Sebaliknya pendidikan yang kurang akan menghambat perkembangan perilaku seseorang terhadap nilai-nilai baru. Sehingga seseorang yang berpendidikan rendah cenderung sulit untuk menyerap informasi daripada orang yang berpendidikan tinggi. Pendidikan SD dikategorikan dalam jenjang pendidikan rendah, sehingga daya pikir responden untuk menerima informasi atau pengetahuan yang diterima tentang mengontrol pola makan sehat dan pola hidup sehat juga rendah, sehingga akan sulit menerima informasi dan menginterprestasikan suatu objek atau materi sehingga perilaku-perilaku yang terbentuk menjadi buruk. Peneliti berpendapat bahwa jenjang pendidikan sangat mempengaruhi perilaku seseorang terhadap suatu objek.

Faktor ke empat yang mempengaruhi perilaku baik keluarga dalam mengontrol fkator risiko penyakit hipertensi adalah sumber informasi. Berdasarkan sumber informasi pada table 1. didapatkan hasil penelitian pada responden yang pernah memperoleh informasi sebanyak 95 responden atau (95\%), sedangkan yang memperoleh sumber informasi dari tenaga kesehatan sebanyak 44 responden (46\%). Dari 44 responden yang memperoleh sumber informasi dari tenaga kesehatan, 24 responden (55\%) mempunyai perilaku baik. Sedangkan responden yang memperoleh informasi dari media elektronik sejumlah 40 responden atau (42\%). Dari 40 responden tersebut 22 responden (55\%) mempunyai perilaku buruk. Menurut teori Notoatmodjo (2003) bahwa dengan memberikan informasiinformasi terlebih dahulu cara-cara hidup sehat, cara pemeliharaan kesehatan, cara menghindari penyakit dan sebagainya akan menyebabkan orang berperilaku sesuai dengan apa yang dia peroleh. Menurut Notoatmodjo (2003), media massa dan elektronika disebut media pendidikan, karena alat tersebut merupakan alat saluran untuk menyampaikan kesehatan dan alat tersebut merupakan alat saluran untuk menyampaikan kesehatan dan alat tersebut digunakan untuk mempermudah penerimaan pesan-pesan bagi masyarakat atau klien. Sehingga informasi dari tenaga kesehatan dapat menuntut pasien untuk berperilaku baik, karena tenaga kesehatan dianggap sebagai petugas yang benarbenar paham tentang ilmu kesehatan. Selain itu, jika informasi yang didapat dari media massa dan elektronika tersebut tepat, maka dapat membentuk pemahaman dan pemikiran yang baik sehingga responden memiliki perilaku yang baik dalam mengontrol factor risiko hipertensi. Namun informasi tidak mutlak mempengaruhi perilaku menjadi baik adapun responden yang tidak mendapatkan informasi mempunyai pengetahuan baik, hal tersebut dapat dipengaruhi oleh pengalaman yang didapatkan, atau tingkat pendidikan. Hal ini dibuktikan dari hasil penelitian dari 5 responden yang tidak pernah mendapatkan informasi, 3 responden $(60 \%)$ mempunyai perilaku baik. Namun perlu diketahui juga bahwa pada penelitian ini informasi tidak selalu menjadi pengaruh terhadap perilaku agar menjadi baik, terbukti bahwa pada penelitian ini terdapat responden yang memiliki perilaku baik adalah responden yang tidak pernah mendapatkan informasi dibandingkan dengan responden yang pernah 
mendapatkan informasi tentang pola pola makan sehat dan pola hidup sehat yang dilakukan keluarga dalam mengontrol penyakit hipertensi keluarga, hal tersebut dipengaruhi oleh banyak hal diantaranya adalah faktor pendidikan. Menurut Notoatmodjo (2003), mengungkapkan bahwa semakin banyak panca indera yang digunakan manusia untuk menerima semakin banyak dan semakin jelas pengetahuan yang diperoleh.

Perilaku buruk keluarga dalam mengontrol faktor risiko hipertensi pada masyarakat desa di Ponorogo terkait dengan kebiasaan keluarga kurang dapat menyediakan makanan yang sehat bagi penderita hipertensi seperti kurang menyediakan buah (pisang) dan susu, serta masih belum membatasi jumlah konsumsi garam bagi anggota keluarga. Garam merupakan hal yang sangat penting pada mekanisme timbulnya hipertensi. Pengaruh asupan garam terhadap hipertensi melalui peningkatan volume plasma (cairan tubuh) dan tekanan darah. Keadaan ini akan diikuti oleh peningkatan ekskresi kelebihan garam sehingga kembali pada keadaan hemodinamik (sistem pendarahan) yang normal. Pada hipertensi esensial mekanisme ini terganggu, di samping ada faktor lain yang berpengaruh (Yundini, 2006). Keluarga masih menyediakan menu makanan yang sama bagi seluruh anggota keluarga, hal ini terkait dengan masalah ekonomi keluarga maupun pekerjaan keluarga.

Perilaku baik keluarga adalah dengan melarang seluruh anggota keluarga khususnya bagi penderita hipertensi untuk minum alkohol. Keluarga sudah tahu efek alkohol yang tidak baik bagi kesehatan.Peningkatan dosis alcohol dikaitkan dengan peningkatan mortalitas kardiovaskuler karena aritmia, hipertensi

\section{DAFTAR PUSTAKA}

Azwar, Saifuddin. 2008. Penyusunan Skala Psikologi. Yogyakarta : Pustaka Pelajar

Hananta Yuda, I Putu. 2011. Deteksi Dini dan Pencegahan 7 Penyakit sistemik dan kardiomiopati dilatasi (Huon, 2002). Keluarga sudah berperilaku baik dengan tidak meminum alcohol bagi penderita hipertensi.

Perilaku keluarga dalam mengontrol faktor risiko penyakit hipertensi pada masyarakat desa di Ponorogo terbanyak adalah perilaku buruk. Model perilaku keluarga yang dominan dalam mengontrol faktor risiko penyakit hipertensi pada masyarakat pedesaan di Kabupaten Ponorogo adalah dengan mengontrol pola hidup sehat, yaitu keluarga menyediakan waktu olahraga secara teratur, menjaga suasana rumah yang tentram dan nyaman, menyelesaikan masalah di keluarga secara baik, tidak merokok dan kontrol kesehatan secara teratur.

Keluarga penderita hipertensi untuk selalu menjaga dan mengontrol pola makan sehat dan pola hidup sehat agar faktor risiko apa saja yang menyebabkan penyakit hipertensi yang diderita keluarga dapat terkontrol.

Masyarakat berusaha secara bersama-sama untuk menghindari faktorfaktor risiko yang dapat menyebabkan penyakit hipertensi, terutama faktor risiko yang bisa dimodifikasi/ diubah seperti obesitas, konsumsi kopi, merokok dan konsumsi garam berlebih. Mengontrol faktor risiko tersebut berguna untuk mencegah terjadinya komplikasi dari penyakit hipertensi seperti penyakit stroke.

Setelah penelitian ini diperoleh data tentang perilaku keluarga dalam mengontrol faktor risiko penyakit hipertensi pada masyarakat desa. Untuk keberlanjutan dari penelitian ini maka peneliti selanjutnya akan meneliti peran keluarga dengan tingkat kepatuhan penderita hipertensi pada masyarakat perkotaan di Ponorogo.

Penyebab Mati Muda. Yogyakarta: Media Pressindo.

Huon, H. 2002. Lecture notes cardiology. Edisi 4, Jakarta : Erlangga Medical Series 
Hurlock, Elizabeth. 2006. Psikologi Perkembangan. Jakarta: Erlangga.

Koentjaraningrat. 2009. Pengantar IImu Antropologi (Edisi Revisi). Jakarta: Rineka Cipta.

Markum, A.H. 2000. Ilmu Kesehatan Anak. Jakarta. Balai Penerbit FKUI

Notoatmodjo, Soekidjo. 2003. Pendidikan dan Perilaku Kesehatan. Jakarta: Rineka Cipta

Notoatmodjo, Soekidjo. 2003. Prinsipprinsip Dasar IImu Kesehatan Masyarakat.Cetakan ke-2 Jakarta: Rineka Cipta

Notoatmodjo, Soekidjo. 2005. Metodologi Penelitian Kesehatan. Jakarta: Rineka Cipta
Nur, Muhammad Lafi Naim. 2012. Hubungan Tingkat Pengetahuan Dengan Perilaku Hidup Bersih Dan Sehat (PHBS) Dalam Penyajian Makanan Pada Pedagang Makanan (Angkringan). Ponorogo: FIK UMP

Sutedjo. 2006. Profil Hipertensi pada Populasi Monica. Hasil Penelitian MONICA-Jakarta III", Jakarta: Filed Under Riset Epidemiologi

Yundini. 2006. Faktor Risiko Hipertensi. Jakarta: Warta Pengendalian Penyakit Tidak Menular, diakses tanggal 16 November 2012 pukul $10: 27$ 